\title{
Warunki praktykowania edukacji domowej w Polsce
}

\section{KEYWORDS}

homeschooling, education regulations, the right to education, learning duty, school duty

\begin{abstract}
Magdalena Giercarz-Borkowska, Warunki praktykowania edukacji domowej w Polsce [Conditions for the practice of homeschooling in Poland]. Kultura - Społeczeństwo Edukacja nr 2(20) 2021, Poznań 2021, pp. 231-239, Adam Mickiewicz University Press. ISSN 2300-0422, ISSN (Online) 2719-2717. DOI 10.14746/kse.2021.20.14
\end{abstract}

The article concerns the subject of homeschooling practice conditions in Poland - it focuses on the legal conditions and outlines the socio-economic conditions in which Polish homeschoolers operate. It discusses the specific kind of right which is the right to education, its position in the systematics of the constitution and the connection to the learning duty and school duty. It brings attention to state-citizen relations and the rule of state subsidiarity. It points to legal regulations which allow realization of the school duty outside of school, underlining the controversial and discriminatory regulations which ignore the parents' priority to decide on their own children's education and treat children learning in this way unequally to those who attend school. The article is ended by an observation about the state remaining decisive on the form of education of each citizen, despite the constant change of legal regulations, which in relation to the discussed subject characterizes the last three decades.

\section{Warunki prakłykowania edukacji domowej w Polsce}

„Edukacja domowa” to coraz popularniejsze w Polsce hasło. Oznacza uczenie się dzieci w trybie zorganizowanym przez rodzinę i na odpowiedzialność rodziców,

* ORCID: https://orcid.org/0000-0002-3097-4573. 
bez udziału szkoły w procesie rozwoju dziecka, który to proces przebiega w zgodzie z familijnie podzielanymi wartościami, w istotny sposób angażuje całą rodzinę i prowadzi do wytworzenia specyficznego dla niej stylu życia. Zaproponowany sposób rozumienia pojęcia „edukacja domowa” sformułowałam po wieloletnich badaniach terenowych (Giercarz-Borkowska 2019), poprzedzonych studiami literaturowymi. Ten polski termin wywodzi się z piśmiennictwa brytyjskiego (tłumaczenie pracy: Meighan, 1991), a nade wszystko z tamtejszej praktyki edukacyjnej, gdzie funkcjonuje określenie home education. W Polsce popularniejsze jest amerykańskie homeschooling, a inne określenia, z którymi można spotkać się to: nauczanie domowe (szczególnie dla nazwania praktyki uczenia domowego w przeszłości), kształcenie domowe lub szkoła domowa (rzadko). Najpopularniejszą z nazw funkcjonujących dla określenia sytuacji, w której dziecko uczy się, lecz z wyboru nie uczęszcza do szkoły jest „edukacja domowa”. Pojęcia tego używała w swoich pracach Hanna Zielińska (1996, 2000), analizująca Illichowską koncepcję „odszkolnienia społeczeństwa”, a później Marek Budajczak (2004) opublikował książkę pod takim tytułem (pierwotne wydanie w 2002 roku). To tam badacz ten, a jednocześnie praktykujący homeschooling rodzic, po raz pierwszy zdefiniował termin „edukacja domowa”, a następnie spopularyzował go w kolejnych publikacjach i dzięki działalności naukowej oraz aktywności społecznej w tym obszarze.

\section{Między prawem a obowiązkiem}

Każdy w Polsce - niezależnie od wieku i innych cech - ma prawo do nauki, które wynika z Konstytucji RP ${ }^{1}$. Niektórzy jednak mają nie tylko prawo, lecz obowiązek nauki, a jeszcze węższa grupa ma obowiązek chodzenia do szkoły. Artykuł 70 konstytucji w ustępie 1 (w zaledwie trzech zdaniach) zawiera aż trzy regulacje, które niejako konfrontują interesy państwa i obywatela:

- przyznaje każdemu prawo do nauki;

- nakłada obowiązek nauki na osoby do 18. roku życia;

- wprowadza obowiązek szkolny i co do jego wykonywania odsyła do ustawy.

Prawo do nauki wprowadzono jako zasadę konstytucyjną już w 1921 roku i utrzymano w kolejnych wersjach z lat: 1935, 1952, 1976, 1991 i 1997 (Piech, 2016: 60). Jest ono jednym z podstawowych praw dziecka i praw człowieka. Jako takie zostało ujęte w wielu aktach międzynarodowych (jak Konwencja o prawach dziecka

\footnotetext{
${ }^{1}$ Konstytucja Rzeczypospolitej Polskiej z dnia 2 kwietnia 1997 roku, DzU z 1997 r. nr 78 poz. 483 z późn. zm.
} 
i inne; Helios, 2014: 186; Helios, Jedlecka, 2015: 109). Państwo ma gwarantować realizację tego prawa poprzez zapewnienie powszechnego, bezpłatnego dostępu do kształcenia, systemu pomocy finansowej dla uczniów oraz możliwość wyboru szkoły innej niż publiczna. Z prawa obywateli wynikają więc obowiązki państwa.

Ustanowione w konstytucji obowiązki obywateli (związane z tym prawem) zapisano w Prawie oświatowym (dalej: UPO)². Może wydawać się sporne, że wobec praw i wolności obywatelskich, prawa rodziców do wychowania dziecka zgodnie z własnymi przekonaniami (art. 48 ust. 1 konstytucji), a także w kontekście praw dziecka, państwo nakłada na dzieci przymus - obowiązek nauki i obowiązek szkolny. Konflikt ten jest szeroko komentowany w pracach Budajczaka (2004), Justyna Piskorskiego (2011), Andrzeja Polaszka (2011) i innych.

Trzeba podkreślić, że prawo do nauki wraz z towarzyszącymi mu obowiązkami traktowane jest w konstytucji jako jedna $\mathrm{z}$ wolności i praw ekonomicznych, socjalnych i kulturalnych, przy czym w literaturze nie ustalono konsensusu co do sposobu postrzegania tego prawa raczej jako prawa socjalnego czy kulturalnego łączonego z ekonomicznym. Z pewnością jednak prawo to ma przynieść wartość jednostce, ale też ogółowi społeczeństwa (Piech, 2016: 61), co stanowi o łączeniu go z obowiązkami obywateli. Przemysław Sztejna zwraca uwagę, że każdy obowiązek nakładany przez państwo jest rodzajem reglamentacji swobód obywatelskich, zatem by go zrozumieć, należy dociec intencji jego wprowadzenia. W przypadku obowiązku szkolnego autor nie dostrzega kolizji między interesem publicznym a prawami i swobodami małoletnich oraz prawami rodziców, gdyż interesy te są wg niego tożsame. Sztejna argumentuje, że kształcenie sprzyja podniesieniu wykształcenia jednostki, ale i społeczeństwa, obowiązek ten ma na celu likwidowanie analfabetyzmu na świecie, osoby małoletnie mogą mylić się w wyborze właściwych celów ze względu na nikłe rozeznanie, a rodzice, którzy nie są w stanie samodzielnie wykształcić dzieci („bez uszczerbku dla jakości kształcenia oraz posiadanych środków finansowych" (sic!)) winni otrzymać od państwa pomoc w tym zakresie. Konstatuje, że same obowiązki (nauki i szkolny) nie mogą być kwestionowane, ale można rozważać ich zakres i treść (Sztejna, 2005: 134-136).

Po przeanalizowaniu relacji między jednostką a państwem w obszarze edukacji, także Piskorski (2011) uznaje, że zrozumiałe są określone oczekiwania edukacyjne państwa wobec obywateli, jednak nie akceptuje prawa do narzucania obywatelom formy kształcenia. Podkreśla potrzebę refleksji nad celami edukacji, zaznaczając, że państwa nastawione na obowiązkową skolaryzację to te, które realizują więcej ukrytych celów edukacji niż jawnie deklarowanych. Zakres ingerencji

\footnotetext{
${ }^{2}$ Ustawa z dnia 14 grudnia 2016 roku Prawo oświatowe, DzU z 2017 r. poz. 59 z późn. zm.
} 
państwa w przebieg kształcenia obywateli „ujawnia rzeczywistą konstrukcję roli państwa” wobec nich. Zdaniem autora ochronnej roli prawa wobec edukacyjnej wolności sprzyjałoby skonstruowanie pola decyzji prawodawczych co do edukacji na podstawie trzech filarów: „prawo do nauki, uprawnienie państwa do określenia niezbędnego poziomu wykształcenia oraz prawo rodziców do wyboru określonego modelu kształcenia i wychowania dzieci” (Piskorski, 2011: 59-60). Autor podnosi tu istotny problem, pominięty przez Sztejna, który zdaje się nie dostrzegać ukrytej funkcji systemu edukacji. Tymczasem wiedza z zakresu socjologii edukacji i pedagogiki szkoły nie pozostawia złudzeń co do tego, że systemy oświatowe, oprócz celów, które deklarują, realizują również inne - o wątpliwej wartości dla jednostek i społeczeństwa. Wśród nich można wskazać choćby takie, jak stratyfikacja społeczna, transmisja kultury, adaptacja, unifikacja i im podobne. Rodzice przekonani o wartości edukacji domowej nie chcą więc, by ich dzieci zmuszano do uczenia się w szkołach i podnoszą argumenty o prawie pierwszeństwa rodziców do decydowania o edukacji własnych dzieci. Społeczeństwa obywatelskie powinny działać zgodnie z zasadą subsydiarności, na której oparty jest ustrój Unii Europejskiej, a zatem tam, gdzie to możliwe, państwo winno pozostawić pole do działania obywateli - pomagać zaś w tych obszarach, w których jednostki czy rodziny nie mogą sobie poradzić.

Homeschoolersi i badacze edukacji domowej wywodzą prawo pierwszeństwa rodziców w wychowywaniu dzieci z aktów międzynarodowych (jak Powszechna Deklaracja Praw Człowieka, Konwencja UNESCO przeciw dyskryminacji w edukacji czy Karta praw podstawowych Unii Europejskiej), jednocześnie wskazując na zawarte w nich niekonsekwentne zapisy. Chrześcijanie ponadto opierają na Biblii przekonanie o tym, że odpowiedzialność za wychowanie dzieci spoczywa na rodzicach (Budajczak, 2017: 54-55; Kucharska, 2014: 215). Grzegorz Harasimiak przypisuje główną rolę rodzicom w realizacji tego prawa, odwołując się do nauki Kościoła i Kodeksu prawa kanonicznego. Państwo nie może narzucić rodzicom rozwiązań w tym względzie, a jedynie służyć pomocą. Winni oni „zmierzać do doskonalenia życia osobowego i społecznego swojego potomstwa" i samodzielnie wybierać, czy zechcą skorzystać ze szkół. Nie narzuca jednak poglądu, że rodziny katolickie powinny wybierać edukację domową - przeciwnie, twierdzi, że nie jest ona koniecznością. Forma edukacji oraz to, „,zy w ten sposób dojdzie do zredukowania, zmiany lub nawet wyeliminowania szkoły jako instytucji biorącej w niej udział, zależy od wyboru dokonanego przez rodziców” (Harasimiak 2011: 50).

Niezależnie od tych poglądów wszelkie przekonania edukatorów domowych co do decyzyjności rodziców pozostają w sferze postulatów, ponieważ kolejne zmiany przepisów podtrzymują nierówny układ sił między państwem a rodzicem. 


\section{Podstawa prawna edukacji domowej i formalne warunki jej praktykowania}

Obowiązek szkolny rozpoczyna się w roku kalendarzowym, w którym dziecko kończy 7. rok życia i trwa do ukończenia szkoły podstawowej, nie dłużej jednak niż do 18. roku życia (art. 35 UPO). Górna granica wynika z obowiązku nauki, który obejmuje osoby do ukończenia 18 lat. Formą spełniania obowiązku szkolnego jest uczęszczanie do szkoły, a więc udział w realizacji ramowego planu nauczania, planu lekcji oraz podstawy programowej zorganizowanych przez sieć publicznych i niepublicznych szkół (Sztejna, 2005: 139). Obowiązku tego nie można uniknąć. Można jednak zrezygnować z chodzenia do szkoły i spełniać obowiązek szkolny poza nią. Przewiduje tę możliwość art. 37 ust. 1 UPO, który stanowi prawną podstawę homeschoolingu w Polsce.

Wskazany przepis nie daje jednak obywatelom możliwości prostego wyboru. Aby realizować obowiązek szkolny poza szkołą, nie wystarczy wola i podjęcie stosownej decyzji. Rodzice zainteresowani edukowaniem domowym są zobligowani do uzyskania zezwolenia dyrektora szkoły. Do niedawna musiała być to szkoła położona na terenie województwa zamieszkania dziecka. To istotne ograniczenie, tym bardziej, że do wydania takiego zezwolenia konieczna była z kolei opinia publicznej poradni psychologiczno-pedagogicznej. Rodzice winni byli dołączyć ją do wniosku o wydanie zezwolenia na spełnianie obowiązku szkolnego poza szkołą. Państwo polskie zrezygnowało $\mathrm{z}$ tej rejonizacji oraz konieczności przedkładania opinii poradni zaledwie kilka miesięcy temu, wprowadzając zmianę w ustawie Prawo oświatowe, która to zmiana obowiązuje od 1 lipca 2021 roku$^{3}$. Z poprzednich wymagań obecnie pozostała jedynie konieczność dołączenia do wniosku oświadczenia o zapewnieniu dziecku warunków umożliwiających realizację podstawy programowej obowiązującej na danym etapie edukacyjnym, a także zobowiązanie do przystępowania przez dziecko w każdym roku szkolnym do rocznych egzaminów klasyfikacyjnych (art. 37 ust. 2 pkt 1 i 2 UPO).

Wspomniane regulacje, które ograniczały terytorialnie wybór szkoły i wymagały przedłożenia opinii wydanej przez publiczną poradnię, obowiązywały od 1 września 2017 roku i zastąpiły wcześniejsze, o szerszym zakresie swobód. Przegląd zmian prawa dotyczących edukacji domowej (postulowanych i wprowadzonych) omawiają szeroko - w okresie, który można było objąć daną publikacją Polaszek (2011), Szymon Paciorkowski (2014), Magdalena Giercarz-Borkowska (2019).

\footnotetext{
${ }^{3}$ Ustawa z dnia 17 marca 2021 r. o zmianie ustawy Prawo oświatowe, DzU z 2021 r. poz. 762.
} 
To, co - poza niestabilnością obowiązujących rozwiązań - najbardziej kontrowersyjne i dyskryminujące w funkcjonujących w ostatnim trzydziestoleciu kolejnych regulacjach, a także krytykowane przez środowisko edukatorów domowych i dolegliwe dla rodzin to konieczność:

- uzyskania zezwolenia zamiast możliwości podjęcia decyzji przez rodzica;

- poddania dziecka badaniom w poradni psychologiczno-pedagogicznej (dodatkowo: publicznej, a zatem rejonowej, co nie pozwalało dokonać swobodnego wyboru i stwarzało konieczność długiego oczekiwania na terminy badań) - dzieci realizujące obowiązek w szkole nie są i nie były poddawane takim obligatoryjnym badaniom;

- corocznego zdawania przez dziecko egzaminów klasyfikacyjnych z zakresu części podstawy programowej obowiązującej na danym etapie kształcenia uzgodnionej z dyrektorem szkoły (art. 37 ust. 4 UPO) w terminie z nim uzgodnionym (art. 441 ust. 2 UOSO $^{4}$ ) oraz obligatoryjny powrót do nauki w trybie szkolnym, gdy uczeń nie zda takiego egzaminu (konsekwencją jest cofnięcie zezwolenia - art. 37 ust. 8 pkt 2 UPO) - podczas, gdy dzieci uczące się w szkołach zdają jedynie egzamin po zakończeniu szkoły podstawowej i egzamin maturalny.

Dodatkowo kontrowersyjny jest taki stan prawny, w którym dyrektor szkoły nie jest zobligowany do wydania zezwolenia ( $w$ art. 37 ust. 1 UPO użyto sformułowania „może zezwolić”, nie zaś „zezwala”), a nie zostały określone przesłanki, dla których mógłby takiego zezwolenia nie wydać. Napięte stosunki między władzami oświatowymi a rodzicami ubiegającymi się o edukację domową skutkują sporami, łącznie z rozpatrywaniem skarg przez sądy administracyjne. Przykład sprawy toczącej się przed Wojewódzkim Sądem Administracyjnym w Lublinie i Naczelnym Sądem Administracyjnym przytacza Paciorkowski (2014). Kompetencje dyrektora szkoły względem decyzji o spełnianiu obowiązku szkolnego poza szkołą to tylko jeden z przykładów, które pokazują, że z jednej strony państwo rości sobie prawo do obwarowania homeschoolingu licznymi nakazami, z drugiej zaś ustanawia bardzo nieprecyzyjne przepisy.

Wachlarz opresyjnych i dyskryminujących przepisów prawa dotyka rodziców, którzy są zmuszeni dopełnić formalności związanych z uzyskaniem zezwolenia, ale też jest niesprawiedliwy dla dzieci, które poddają się corocznemu przedmiotowemu egzaminowaniu. Postanowienia związane z klasyfikacją uczniów w trybie edukacji domowej są - z konieczności - ogólne i wyznaczają jej podstawowe (poza wcześniej wspomnianymi) cechy, jak: forma egzaminu (pisemna i ustna),

\footnotetext{
${ }^{4}$ Ustawa z dnia 7 września 1991 roku o systemie oświaty, DzU z 1991 r. nr 95 poz. 425 z późn. zm.
} 
wykaz przedmiotów, które nie podlegają weryfikacji (WF, muzyka, plastyka, technika, dodatkowe zajęcia edukacyjne) oraz wskazują skład komisji egzaminacyjnej i możliwość obserwowania przebiegu egzaminu przez rodzica ucznia ${ }^{5}$. Brak szczegółowych regulacji skutkuje dowolnością działania szkół co do kształtu i przebiegu konkretnego egzaminu. To z kolei powoduje, że oprócz egzaminów rzetelnych, organizowanych z poszanowaniem praw i możliwości psychofizycznych ucznia, bywają organizowane także tzw. „małe matury”, polegające na wielogodzinnym testowaniu. Jedynym zabezpieczeniem prawidłowego - z psychopedagogicznego punktu widzenia - przebiegu egzaminu jest doświadczenie i mądrość dyrektorów szkół. Ma to niebagatelne znaczenie, ponieważ dziecko zdające egzamin przeżywa stres związany nie tyle z samą sytuacją egzaminacyjną, co z konsekwencjami niezdania takiego egzaminu. Szczęśliwie dla rodzin edukacji domowej przybywa w Polsce szkół zaznajomionych $\mathrm{z}$ ideą homeschoolingu.

Powyższe spostrzeżenia co do warunków prawnych sygnalizują jedynie problem, podejmowany wcześniej zarówno przeze mnie (2019), jak i przez innych badaczy (np. Paciorkowski 2014, liczne prace Budajczaka). Szersze ich omówienie przekracza możliwości tego opracowania. Można te warunki - za Budajczakiem (2017) - uogólnić określeniem „niejednoznaczne i ambiwalentne”.

\section{Warunki społeczno-ekonomiczne}

Niestabilne i dyskryminujące przepisy prawa to nie jedyny element w grupie warunków, w jakich działają polscy homeschoolersi. Istotną kategorię tworzą też warunki społeczno-ekonomiczne, które są związane i z działaniami państwa, i z postawami społeczeństwa wobec homeschoolingu.

Dyskryminacja prawna prowadzi w prosty sposób do dyskryminacji ekonomicznej edukatorów domowych. Ich wysiłki nie są w żaden sposób wspierane przez państwo. Wszelkie koszty związane $\mathrm{z}$ realizacją edukacji $\mathrm{w}$ rodzinie ponoszą we własnym zakresie, przy czym trzeba zauważyć, że wybór edukacji domowej często wiąże się z ograniczeniem możliwości zarobkowania lub całkowitym zaprzestaniem pracy zawodowej przez jedno z rodziców, zwykle matkę (Giercarz-Borkowska, 2020a). Dodatkowo państwo polskie przekazuje do szkół niższą subwencję (60\%) na uczniów, którym wydano ww. zezwolenie niż na tych, którzy do niej regularnie uczęszczają. O ile można obronić stanowisko, że uczeń edukacji domowej nie generuje w szkole takich samych kosztów, jak uczeń obecny tam codziennie, o tyle nie

\footnotetext{
${ }^{5}$ Rozporządzenie Ministra Edukacji Narodowej z dnia 22 lutego 2019 roku w sprawie oceniania, klasyfikowania i promowania uczniów i słuchaczy w szkołach publicznych, DzU z 2019 r. poz. 373.
} 
można udawać, że koszty edukacji takiego dziecka nie występują. Przyjęte rozwiązania pomijają je milczeniem. Dzieci te straciły prawo do części kwoty, którą rząd standardowo przeznacza na ucznia - pomocnicza rola państwa nie jest realizowana.

Dopełnieniem warunków działania rodzin edukacji domowej w Polsce są postawy społeczeństwa wobec omawianej idei: budzi sprzeciw, wyzwala lęk, intryguje, niektórych kusi, innych oburza. Wraz z liczebnym wzrostem populacji homeschoolersów reakcje otoczenia okazywane praktykom homeschoolingu stają się jednak łagodniejsze - Polacy stopniowo zaczynają osłuchiwać się z pojęciem „edukacja domowa”, a dzieci i rodziców rzadziej spotyka odrzucenie w rodzinach, kręgach towarzyskich czy w sąsiedztwie. Na edukację domową decydują się czasem nawet - poddawane ze względu na specyfikę swojego działania i tak wzmożonej kontroli społecznej - rodziny zastępcze, choć czynią to nie bez lęku przed nieufnością otoczenia (Giercarz-Borkowska, 2020b).

Wiedza o nauczaniu domowym nie została przeniesiona do czasów nam współczesnych przez pamięć pokoleń - ta niesie bowiem ze sobą pamięć obowiązku szkolnego, w którym wychowane zostało niemal 100\% współcześnie żyjących rodziców i polityków, decydujących o kształtowaniu prawnych warunków nauki. Stąd nie można dziwić się dystansowi, z jakim społeczeństwo podchodzi do pomysłu uczenia dzieci bez posyłania ich do szkoły. Można natomiast - i warto - popularyzować wiedzę o edukacji domowej po to, aby poszerzać horyzonty społeczne i umożliwiać świadome podejmowanie decyzji.

W ciągu trzech ostatnich dekad w warunkach praktykowania edukacji domowej w Polsce zmieniło się wiele - zmieniano także kierunki tych zmian. Stopniowa liberalizacja przepisów prawa regulujących dostęp do krajowego homeschoolingu ustąpiła miejsca ich zaostrzeniu, by w połowie 2021 roku znów przybrać kształt mniej restrykcyjny; początkowy ostracyzm społeczny przeobraża się w kierunku zdystansowanego zainteresowania, a sama społeczność bardzo się rozrasta. Niezmienna pozostaje zasada, którą dekadę wcześniej podkreślił w swoim tekście Polaszek (2011). Pomimo najnowszych zmian prawnych nadal decydujący głos w sprawie edukacji dziecka należy do państwa, nie do rodziców.

\section{Bibliografia}

Budajczak M. (2004), Edukacja domowa, Gdańsk.

Budajczak M. (2017), Polska edukacja domowa jako mise en abyme między kondycją ludzką a społecznymi konstrukcjami oświatowymi, Studia Pedagogica Ignatiana, t. 20, nr 3, s. 47-62.

Giercarz-Borkowska M. (2019), Edukacja domowa jako alternatywa edukacyjna dla dzieci zdolnych, Wrocław. 
Giercarz-Borkowska M. (2020a), Między pracą zawodową a edukacją dzieci - sytuacja zawodowa rodziców edukujących domowo, Edukacja Dorosłych, nr 1, s. 83-97.

Giercarz-Borkowska M. (2020b), Piecza zastępcza a edukacja domowa - zarys perspektywy opiekunek, [w:] P. Kaszubska-Dziergas, J. Tomczyk (red.), Rodzicielstwo zastępcze - w poszukiwaniu modelu wsparcia i animowania wspótpracy środowiskowej, Opole, s. 121-138.

Harasimiak G. (2011), Obowiązek zapewnienia edukacji dzieci w świetle prawa kanonicznego, [w:] J. Piskorski (red.), Szkoła domowa. Między wolnościq a obowiązkiem, Warszawa, s. 41-51.

Helios J. (2014), Edukacja domowa - kilka uwag w kontekście dyskursu o edukacji demokratycznej, Filozofia Publiczna i Edukacja Demokratyczna, tom III, nr 2, s. 180-198.

Helios J., Jedlecka W. (2015), Dysocjacja jako hard case w systemie prawa, Wrocław.

Konstytucja Rzeczypospolitej Polskiej z dnia 2 kwietnia 1997 roku, DzU z 1997 r. nr 78 poz. 483 z późn. zm., http://prawo.sejm.gov.pl/isap.nsf/DocDetails.xsp?id=WDU19970780483, dostęp: 08.04.2020.

Kucharska A.M. (2014), Dlaczego edukacja domowa? Aksjologiczne uzasadnienia edukacji bez szkoły, Wychowanie w rodzinie, t. X, nr 2, s. 205-224.

Meighan R. (1991), Edukacja elastyczna. Jutro twojego dziecka decyduje się dzisiaj, tłum. A. Nalaskowski, Toruń.

Paciorkowski S. (2014), Homeschooling in Poland? Legal Status and Arguments Used in Polish Debate over Home Education, Social Transformations in Contemporary Society, 2, s. 153-162.

Piech K. (2016), Obowiązek szkolny i obowiązek nauki jako realizacja konstytucyjnego prawa do nauki, Ogrody Nauk i Sztuk, 6, s. 59-69.

Piskorski J. (2011), Przymus szkolny czy prawo do edukacji, [w:] J. Piskorski (red.), Szkoła domowa. Między wolnością a obowiązkiem, Warszawa, s. 53-60.

Polaszek A. (2011), Edukacja domowa w świetle obowiązujących przepisów, [w:] J. Piskorski (red.), Szkoła domowa. Między wolnością a obowiązkiem, Warszawa, s. 61-68.

Rozporządzenie Ministra Edukacji Narodowej z dnia 22 lutego 2019 roku w sprawie oceniania, klasyfikowania i promowania uczniów i słuchaczy w szkołach publicznych, DzU z 2019 r. poz. 373.

Sztejna P. (2005), Prawne aspekty obowiązku szkolnego i obowiązku nauki, Studia Lubuskie: prace Instytutu Prawa i Administracji Państwowej Wyższej Szkoły Zawodowej w Sulechowie, 1, s. 133-143.

Ustawa z dnia 7 września 1991 r. o systemie oświaty, DzU z 1991 r. nr 95 poz. 425 z późn. zm.

Ustawa z dnia 14 grudnia 2016 r. Prawo oświatowe, DzU z 2017 r. poz. 59 z późn. zm.

Ustawa z dnia 17 marca 2021 r. o zmianie ustawy Prawo oświatowe, DzU z 2021 r. poz. 762.

Zielińska H. (1996), Ivan Illich. Między romantyzmem a anarchizmem pedagogicznym, Toruń.

Zielińska H. (2000), Neoromantyczne utopie Ivana Illicha, [w:] Z. Kwieciński (red.), Alternatywy myślenia o/dla edukacji, Warszawa, s. 239-253. 
